E3 Journal of Business Management and Economics Vol. 8(1). pp. 018-025 April, 2017

Available online http://www.e3journals.org

ISSN 2141-7482 @ E3 Journals 2017

DOI : http://dx.doi.org/10.18685/EJBME(8)1_EJBME-17-012

Full Length Research Paper

\title{
The role of education inequality in the growth-volatility relationship in MENA region
}

\author{
Amira Emara* and Engy Raouf \\ Department of Economics and Foreign Trade Faculty of Commerce and Business Administration Helwan University.
}

Accepted 29 March, 2017

The main objective of this paper is to investigate the impact of education inequality on the growth-volatility relationship for 12 MENA countries over the period 1970-2010. The study measured inequality of education by calculating an Education Gini Index, then estimate volatility using GARCH model. In order to achieve the main objective of this study, two different econometric techniques have been used-Generalized Method of Moments and the Pooled Mean Group- ARDL estimator. Then we compared the results of the two techniques. The empirical analysis shows that education inequality affects growth negatively. While the volatility has a positive impact on growth, its interaction with education inequality has a negative impact. These results suggest that when policymakers decide to increase investment in education, even during economic downturns, they should take into account the equal distribution of educational services.

Keywords: educational inequality, volatility, economic growth, Education Gini index, MENA, GMM, GARCH, Pooled Mean Group- ARDL.

\section{INTRODUCTION:}

Long-term growth and short-term volatility have been analyzed for a long time as separate phenomena. Now theoretical and empirical studies support the idea that business cycle volatility may affect the average rate of economic growth. Therefore, the government and the private sector should be concerned about the short run effects of business cycle volatility as well as its impacts on achieving long-run growth (Hnatkovska and Loayza, 2003, P. 20).

Many countries in the Middle East and North African (MENA) region witnessed economic and political crises which lead to fluctuations in output and hence the growth pattern. There are a number of channels through which the negative impacts of these fluctuations can be lessened. One of these channels that is expected to lessen this negative effect is the education equality. Therefore, it is expected that the higher the equality of

\footnotetext{
*Corresponding Author Email: amiraemara2000@yahoo.com
}

distribution of education, the lower the growth-volatility adverse effect. As a result, our paper is trying to examine how the distribution of human capital across an economy can affect the negative effect of output volatility on economic growth.

The main contribution of our work is to examine the significance of education inequality in the growth-volatility relationship in order to highlight not only the importance of education but also its distribution in affecting growth volatility relationship. While other papers either study the relationship between volatility and growth only or the impact of education inequality on economic growth.

Hence, our study is concerned with one main question: To what extent does the education inequality affect the growth-volatility relationship. Therefore, the hypothesis under consideration is that education inequality affects the volatility - growth relationship negatively.

In doing so, we calculate the Education Gini Index, as a proxy to education inequality, then analyze its evolution in MENA region in the period 1970-2010. In addition, we estimate volatility using $\mathrm{GARCH}$, then try to explore the impact of education inequality on the growth -volatility 
relationship, using the Generalized Method of Moments and the Pooled Mean Group- ARDL. After that, we compare the results of the two techniques.

The rest of this paper is organized as follows: Section two presents the literature review. Section three explains the procedure used to calculate the Education Gini Index as a measure of human capital inequality, and shows an overview of trends in the education inequality in MENA region. Section four demonstrates data sources of the sample under consideration. Section five includes the models under consideration. Section six illustrates the results of the models estimation. Finally, the last section discusses the conclusions reached.

\section{The role of education inequality in the volatility - growth relationship: Literature review}

The relationship between business-cycle behavior and long-run economic growth and the role of human capital or education in this link has been investigated in many studies. On the other hand, many papers examine the impact of human capital inequality or educational inequality on economic growth in a specific country or countries.

\section{The growth-volatility Link, and The Role of Human Capital or Education in This Link.}

Long-term growth and short-term business cycle volatility have been treated independently for a long time. But now there is a strand of theoretical and empirical literature which studies how volatility may be one of the important determinants of the long-term economic growth. (Kedir and Bani, 2012, P.2). After investigating the association between volatility and growth, some economists found negative links and others found positive (Koteski et al., 2013, P.1).

Ramey and Ramey (1994) conclude that countries with higher volatility of output have lower growth using a sample of 92 countries and a sample of OECD countries, (Ramey and Ramey, 1994, PP.2, 15).

Canton (1996) analyzes the positive impact of cyclical volatility on long term growth using a stochastic twosector model of endogenous growth. He shows that agents will accumulate human capital in order to cover future uncertainty. As a result, agents will increase precautionary savings to meet cyclical fluctuations. It can be concluded that the transmission channel of the interaction between economic growth and business cycles is the accumulation of human capital (Canton, 1996, PP.4, 27).

Using cross-country data, specifically, countryaverages over the period 1960-2000, Hnatkovska and Loayza (2003) conclude that if endogeneity of volatility is ignored and the volatility-growth reverse causality has been concerned, there is a negative relationship between macroeconomic volatility and long-run economic growth. This negative connection is exacerbated when countries are poor, have underdeveloped institutions, are in transitional stages of financial development, or cannot undertake countercyclical fiscal policies. In contrast, the link between volatility and growth may not depend on a country's level of international trade openness (Hnatkovska and Loayza, 2003, PP.5, 19-20).

Kose et al. (2005) conclude that, in general, the volatility - growth relationship has been negative, for a sample of 85 industrial and developing countries over the period 1960-2000. However, the results show that this relationship varies over time and across countries due to increased trade and financial flows (Kose et al., 2005, PP.37, 59).

Regarding the channels through which volatility may affect growth, Martin and Rogers (2000) demonstrate that business cycle fluctuations may decrease the rate of economic growth especially if learning by doing is the origin of growth. Because during recessions, learning by doing is limited, the human capital accumulation is affected negatively. As long as human capital accumulation is increasing during the business cycle disturbance, the wasted learning is not fully recovered when the cycle turns upwards again. This is how business cycle fluctuations can adversely affect long-term growth rates (Martin and Rogers, 2000, P.361).

The main finding of the majority of existing studies Ramey and Ramey (1995), Hnatkovska and Loayza (2005) and Badinger (2010) is that volatility has a detrimental effect on economic growth. Although, when other variables are included in the analysis, the implications become considerably different.

Kedir and Bani (2012) focus on the role of education and provide evidence about the positive effect of the interaction of education and volatility on economic growth. The study uses data of 100 developing countries in Asia, Latin America and Africa from 1970 to 2009. The result was similar to results predicted by Blackburn and Galindev (2003), Canton (2002), Varvarigos (2008) and Blackburn and Varvarigos (2008). According to these studies, volatility increases the precautionary demand for investment in human capital and enhances growth rate (Kedir and Bani, 2012, P.2).

According to Kedir and Bani (2012) education can be the mechanism through which volatility affects growth positively, as education helps to reduce and eliminate the effect of volatility. However, this significant positive impact depends on a country's level of income and volatility. Kedir and Bani (2012) show that education has a positive impact on productivity and innovation and this stimulates growth; this is why the interaction term has a positive sign (Kedir and Bani, 2012, PP.6-7).

Koteski et al. (2013) also prove that there is a positive association between standard deviation of GDP growth and GDP growth on a large sample of pooled crosscountry data (Koteski et al., 2013, P.12). 
Arbache and Sarquism (2017) show that growth volatility and recessions have negative impacts on longterm growth potentials in Brazil. This helps to explain the reasons behind Brazil's growth poor performance and decreasing convergence with advanced economies. The negative effect of volatility can also explain why other developing and emerging countries are still stuck in the middle-income economies (Arbache and Sarquism, 2017, PP. 1, 19).

Trypsteen (2017) examines the relationship between output volatility and growth for 13 OECD countries over the period February 1962 - March 2015. The standard Generalised Autoregressive Heteroscedasticity in Mean (GARCH-M) has been used. Nevertheless, studies using the GARCH-M framework, have conflicting conclusions. Some of those studies indicate that there is a positive relationship between output volatility and growth (Fountas and Karanasos, 2006; Lee, 2010; Fang and Miller, 2014), other studies (Bredin and Fountas, 2009; Henry and Olekalns, 2002) realize it negative, and third studies (Grier and Perry, 2000; Fang et al., 2008) indicate no statistically significant relationship (Trypsteen , 2017, P.1)

Trypsteen (2017) notices that domestic volatility has a positive and statistically significant impact on growth, while the effect of external volatility on growth is negative. These results indicate that the source of volatility is vital in explaining the effect of volatility on growth. As country interactions are important, the effect of volatility on growth differs depending on whether volatility stems from inside or from outside the country (Trypsteen, 2017, PP. $2,10)$.

\section{The impact of human capital inequality on economic growth}

Many studies examined the impact of inequality on economic growth. Some of them examined the impacts of income and land inequality instead of estimating the effects of wealth inequality on economic growth. López, Thomas and Wang, (1998), Thomas, Wang and Fan, (2000), Castelló and Doménech, (2002) and CastellóCliment, (2004) have accounted for the human capital distribution as a possible way to explain differences in output growth between countries (Güngör, 2006, P.3).

Güngör (2006) examines the effect of human capital inequality on economic growth from 1975 to 2000 in the provinces of Turkey. According to this study, the inequality in the distribution of human capital may affect economic growth through two channels. The first channel is the inefficient allocation of resources caused by education inequality, since low education levels and hence distribution of human capital across an economy leads to lower educated workforce, unable to use new technologies efficiently to produce goods and services. Consequently, education inequality is thought to affect economic growth through affecting economic efficiency.
The second channel through which education inequality may influence economic growth is its negative impact on the rate of human capital accumulation which, in turn, leads to lower growth rates (Güngör, 2006, PP. 2, 3). Güngör, (2006) finds that there is a negative relationship between education inequality and growth. This negative relationship was due to inefficiency channel rather than capital accumulation (Güngör, 2006, P.16).

Castelló and Doménech, (2002) also conclude, using data for 108 countries from 1960 to 2000, that human capital inequality indicators are more robust than income inequality indicator in studying the impact of inequality on growth. According to their results, human capital inequality has a negative impact on economic growth rates through its influence on the efficiency of resource allocation and through decreasing investment rates as well (Castelló and Doménech, 2002, PP. C188-C189).

These results are supported by Barro (1991), Barro and Lee $(1993,1997)$, Barro and Sala-i-Martin (1995) and Aghion and Howitt (1998) studies which emphasize that the level of education and its distribution play an important role in determining economic growth. An increase in the average level of education leads to a relative increase in the supply of skilled labor, which in turn, improves average labor productivity and therefore increases the rate of economic growth (lbourk and Amaghouss, 2013, P.111; Rubina and Mirza, 2005, P.3).

In addition, Thomas et al. (2001) found, for 85 countries from 1960 to 1990 , that there is a negative relationship between education inequality and the per capita GDP. They found also a positive association between the average educational attainment and per capita GDP increments (in the preceding period), for both the fixed or random effects or for country -specific effects. Their study also regressed the per capita GDP increments on the average educational attainment and education Gini, and found that the effect of average educational attainment stays positive and significant, but the effect of education Gini becomes insignificant (Thomas et al., 2001, PP.2223).

Rubina and Mirza (2005), showed that educational inequality is the strongest factor which affect economic growth negatively in Pakistan over the period 1973-1998 (Rubina and Mirza, 2005, P.23).

Therefore, all these studies show that human capital endowment played an important role in affecting growth, as distribution of income is determined by the distribution of human capital (Castelló and Doménech, 2002, PP.C187-C188).

This paper, in turn, tries to examine the impact of the distribution of human capital on the growth - volatility relationship.

\section{Gini coefficient (Education Gini Index)}

Gini coefficient is one of the commonly used methods, 
that is used to measure the inequality of schooling in relative term. The concept and method of calculating education Gini is very similar to income Gini. It is calculated using different data; enrollment, financing, and attainment data. Gini coefficient can be measured using two different methods, indirect and direct.

The indirect method constructs the education Lorenz curve. It shows the combination between the cumulative percentage of the schooling years and the cumulative percentage of the population.

On the purpose of estimating education Gini coefficient among MENA region countries, the direct method has been used. According to the direct method, the education Gini is defined as "the ratio to the mean (average years of schooling) of half of the average over all pairs of the absolute deviations between all possible pairs of people" (Deaton 1997). Thomas et al.I (2000) developed Deaton's formula, which is shown in equation 1.

$$
E_{L}=\left(\frac{1}{\mu}\right) \sum_{i=2}^{n} \sum_{J=1}^{i=1} p_{i}\left|y_{i}-y_{j}\right| p_{j}
$$

Where: $E_{L}$ denotes the education Gini based on educational attainment level; $\mu$ is the average years of schooling; pi and pj stand for the shares of population with certain levels of schooling; yi and yj are the years of schooling at different educational attainment levels; $n$ is the number of levels in attainment data.

According to Barro and Lee, attainment levels are classified into 6 categories; illiterate, people who do not complete primary school, people who complete primary school, people who do not complete secondary school, people who complete secondary school, people who do not complete tertiary school, and people who complete tertiary school.

Figure (1) shows that on average the MENA region achieved high level of equality of education from 1970 to 2010. As can be deduced from the figure 2, Israel and Cyprus are the countries where the equalities in education are most pronounced compared with the sample of this study; while the highest level of inequality was in Sudan. All countries have moved towards education equality over the period from 1970 to 2010 .

\section{Data sources}

We collected data for a number of variables, namely educational attainment, GDP, volatility of output and investment. GDP is the per capita GDP growth rate. Volatility is estimated using a GARCH model. Education inequality is measured as education Gini. Investment is the capital formation growth rate as a percentage of GDP. The sample under consideration includes a panel data of the MENA region countries starting from 1970 to 2010 (last education data available from Barro and Lee). The data on education is reported in five - year intervals. Hence, we considered five-year averages of all other variables. The sources of our data are Penn Tables (GDP data), Barro and Lee (2010) database (education data) and the World Development Indicators (WDI) of the World Bank (gross capital formation as a percentage of GDP).

\section{MODEL}

We estimate the relationship between education inequality and growth-volatility using 2 different econometric techniques- GMM and pooled mean group ARDL. Then, we compare the results of the two techniques.

The panel data GMM method is appropriate when the model includes endogenous explanatory variables (Wooldridge, 2001, PP.89-90, 94; Bond, 2002, P.2) and it is expected that the relationship between education inequality and growth-volatility is a two-way relationship.

GMM estimators are more efficient than ordinary least squares and two-stage least squares when there is a problem of heteroskedasticity (Wooldridge, 2001, P.92; Arellano and Bond, 1991, P.293; Baum et al., 2003, P.11). Cragg (1983) was the first to discover that if there is heteroscedasticity, generalized method of moments will be more appropriate than OLS. This means that a GMM will be more efficient in case of panel data, if there is heteroskedasticity or serial correlation (Wooldridge, 2001, PP.90, 97).

In order to remove unobservable individual effects $v_{i}$, GMM takes first difference of the basic equation, because the individual effect represents omitted variables which are correlated with the other regressors (Judson and Owen, 1999, P.11).

$y_{i, t}-y_{i, t-1}={ }_{\theta}\left(y_{i, t-1}-y_{i, t-2}\right)+\left(x_{i, t}-x_{i, t-1}\right)^{\prime} \beta+\left(e_{i, t}-e_{i, t-1}\right)$ (3)

Differenced errors are correlated with the one of the independent variables $\left(\mathrm{y}_{\mathrm{i}, \mathrm{t}-1}-\mathrm{y}_{\mathrm{i}, \mathrm{t}-\mathrm{2}}\right)$ (Judson and Owen, 1999, P.12). Therefore, lagged values of the dependent variable itself, (which are uncorrelated with the disturbance), are valid instruments in the differenced equations (Arellano and Bond, 1991, P.278; Bond, 2002, PP.7-8; Wooldridge, 2001, P.98).

We estimate a dynamic model from panel data using the Generalized Method of Moments (GMM), proposed by Arellano and Bond (1991), for the period 1970-2010 in 12 MENA countries using a 5-years average data.

$\mathrm{GDP}_{\text {it }}=\beta_{0} \mathrm{GDP}_{\mathrm{it}-1}+\beta_{1}$ Vol $_{\mathrm{it}}+\beta_{2} \mathrm{Gini}_{\mathrm{it}}+\beta_{3}$ Vol $_{\text {it }} \times$ Gini it $_{\mathrm{it}}$ $+\beta_{4} \mathrm{GC}_{\text {it }}+v_{\mathrm{i}}+\mu_{\mathrm{t}}+\varepsilon_{\mathrm{it}}$

We model the growth of per capita GDP of country i at the year $t$ as a function of lagged GDP per capita, output volatility (Vol), education Gini (Gini), gross capital formation as a percentage of GDP (GC), and an 


\section{Gini average}

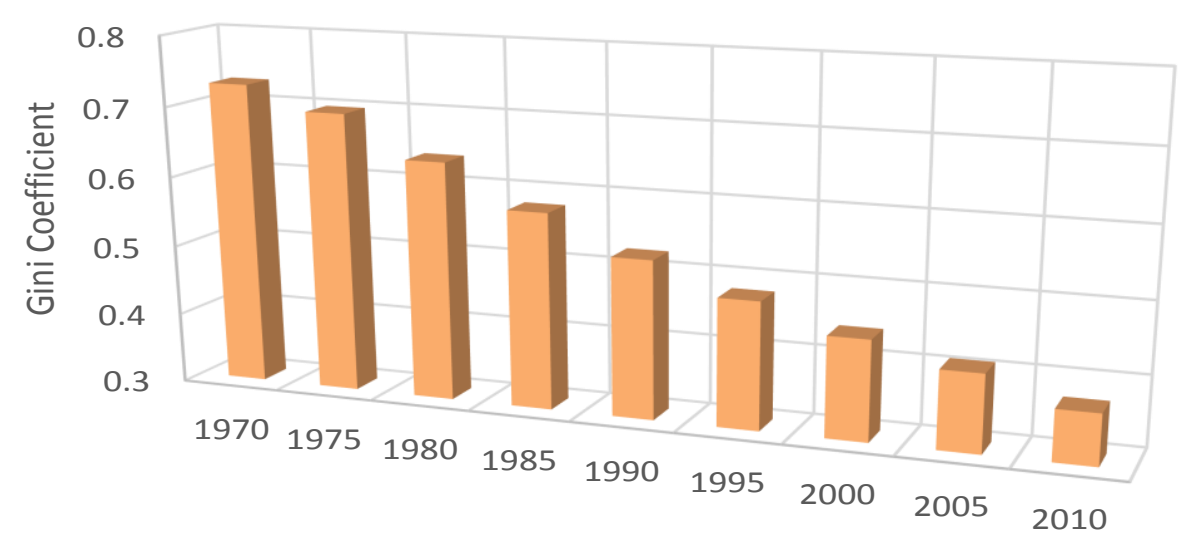

Time

Figure 1. Average of Education Gini for The MENA Region Countries over The Period from 1970 to 2010 (Source: Constructed by the authors based on Barro and Lee school enrollment database)

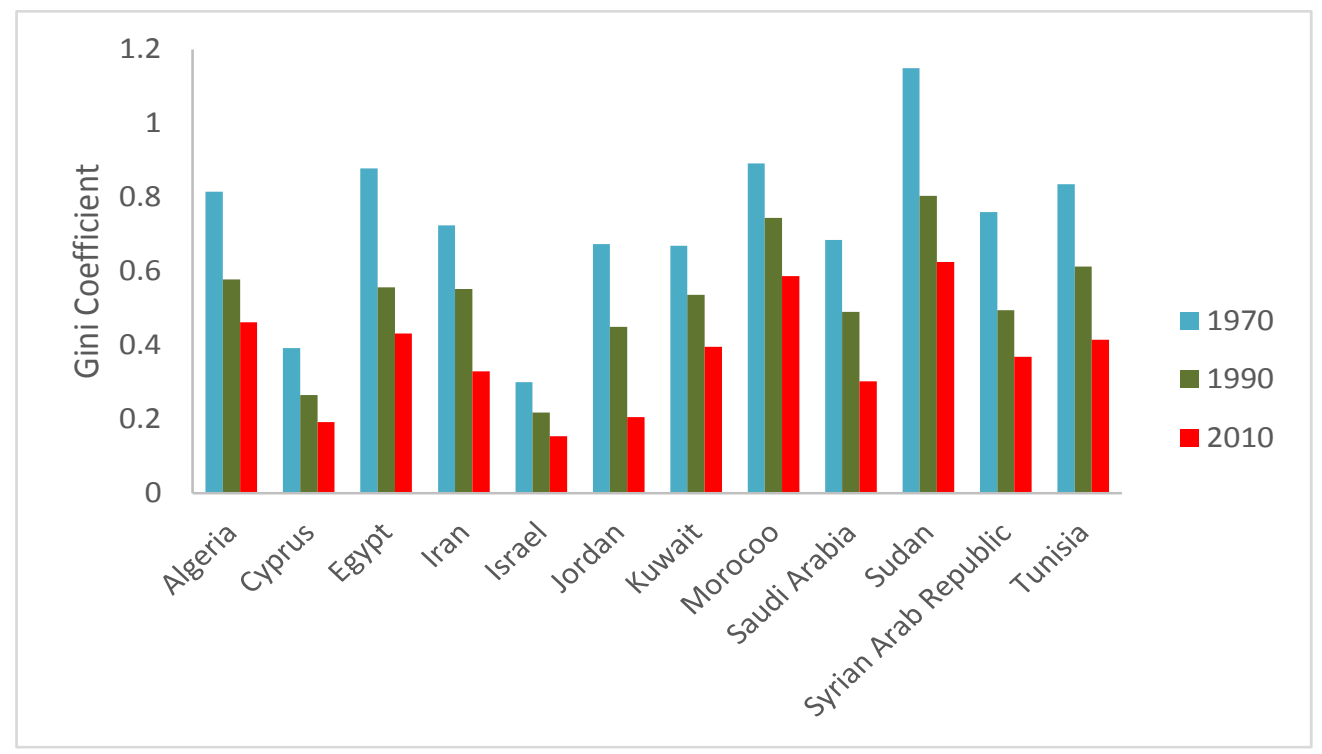

Figure 2. Evolution of Gini Coefficient in MENA countries (Source: Constructed by the authors based on Barro and Lee school enrollment database)

interaction term between education Gini and volatility. We add the unobservable individual effects $\left(v_{i}\right)$, the unobservable time effects $\left(\mu_{\mathrm{t}}\right)$ and the error term $(\varepsilon)$.

Then, we are going to use annual data by fulfilling data using interpolation of missing values and repeat our analysis for the results. In this case, GMM estimators will not be efficient, as Roodman (2006) argues that GMM estimators provide spurious results when $\mathrm{N}$ is small and $\mathrm{T}$ is large. When $\mathrm{N}$ is small so the autocorrelation test will be inaccurate. At the same time, time span ( $T$ ) is large, then the number of instruments will get larger too which will affect the rationality of the Sargan test, test of over identification restriction, and thus results in the rejection of the null hypothesis of the exogeneity of instruments. As a result, the GMM estimators are thought to be unreliable and inconsistent. In addition, GMM denoted only the short-run dynamics.

Based on Pesaran et al. (1999), used the Pooled Mean Group- autoregressive distributed lag model (PMGARDL) in order to take account of both short-run and 
long-run coefficients, including the intercepts and error variances to be heterogeneous country by country, and the long-run slope coefficients which are restricted to be homogeneous across countries (Ren, et al. 2012, Samargandi, et al. 2015).

We use PMG-ARDL model with fully filled data using interpolation for missing values. The relative size of $T$ and $\mathrm{N}$ is important, the dynamic panel technique can be used if both of them are large, and this helps to avoid the bias in the average estimators and resolves the issue of heterogeneity (Samargandi et al. 2015).

\section{RESULTS}

In this section, we will explain the results of estimating the relationship between education inequality and growthvolatility for a sample of MENA region countries over the period 1970-2010 using the two econometric techniques and then compare between them. After running the regression using GMM, we got the following results.

From the GMM model, it can be concluded that Gini and Gini-volatility interaction have negative and significant impacts on GDP per capita growth rate. Volatility, and investment (which is proxied by gross capital formation as a percentage of GDP) have positive and insignificant impacts on GDP per capita growth rate.

We note that all the diagnostic results of the GMM system are satisfactory. We should then test the instruments used, if we have excess instruments which means that the equation is over-identified, then we test whether the instruments are uncorrelated with the error process. Over-identified equation means that the number of instruments excluded from the equation is greater than the number of included endogenous variables (Baum et al., 2003, P.16).

In the context of GMM, the commonly used test to identify the over-identifying restrictions is $\mathrm{J}$-statistic of Hansen (1982). The J-statistic is X2 distributed test with degrees of freedom equal to the number of overidentifying restrictions L-K. J-statistic is used to evaluate the suitability of the model. If the null hypothesis is rejected, this implies that the instruments are not satisfying the orthogonality conditions required for their employment because they are not exogenous, or because they are incorrectly excluded from the regression (Baum et al, 2003, P.16).

Thus, $\mathrm{J}$ - statistic is used to test for significance of the instrumental variables included. According to the results of J-statistic in table (1) we can accept the null hypothesis, so the model is significant in terms of the selection of the instrumental variables.

Now we are going to fulfill annual data and re-estimate the relationship between education inequality and growthvolatility using PMG-ARDL technique. Table 2 presents the result of Pooled Mean Group Estimation using ARDL $(6,6,6,6,6)$. The table shows the long-run and short-run coefficients between GDP and education Gini, volatility and their interactions. In the long run, as can be seen the results show that the volatility is positively and statistically significant at 1 per cent in influencing the GDP per capita growth rate. The education Gini - volatility interaction, education Gini and investment as measured by the growth capital formation are negative and significant. However, in the short-run, all the variables are not statistically significant in influencing the GDP per capita growth rate.

By comparing results of GMM and PMG- ARDL models, it can be concluded that the signs are the same for all variables except investment where it shows negative impact on GDP per capita according to PMGARDL model but positive impact according to GMM. The sign of all other variables are similar in both models but the magnitudes of all of them are higher in the PMGARDL model compared to GMM model except for Gini coefficient.

\section{Conclusion and policy implications}

This paper provides evidence on the effect of education inequality on the growth - volatility relationship using panel data of 12 MENA countries over the period 1970 to 2010.

An important finding that counterparts the results of previous papers is how the distribution of education can influence the business cycle volatility effect on economic growth. The empirical analysis shows that education inequality affects growth negatively as expected, since unequal distribution of education has a negative impact on the rate of human capital accumulation and consequently on the rate of economic growth.

The volatility has a positive effect on growth, this unexpected positive effect indicates that economic crises has a limited or minor effect on the MENA countries. For instance, they have no short-term financial impact on the region. (Hakimian, 1998, P.16). With respect to the global economic crisis, Middle East region has not been affected by recession or a slowdown economic growth like many other parts of the world (Habibi, 2009, P.6). This mild impact can be explained by three reasons. MENA countries are not highly integrated into global financial markets; these countries used a number of actions, such as using expansionary fiscal policies, in order to decease the negative impact of the crisis; For example, Saudi Arabia increased fiscal expenditures by $10.4 \%$ in 2009 , while Egypt and Syria increased it by $14.6 \%$ and $7 \%$ respectively. These expenditures have been directed towards investments in public utilities and infrastructure projects (Habibi, 2009, P.6). Finally, Arab countries have high growth rates during 2007-8, which protect them from contraction (Habibi, 2009, P.8).

While the volatility has a positive effect on growth, its interaction with education inequality has a negative 
Table 1: The Effect of Education Inequality using GMM

\begin{tabular}{lcccc}
\hline Variable & Coefficient & Std. Error & t-Statistic & Prob. \\
\hline GDP(-1) & 0.198372 & 0.040430 & 4.906492 & 0.0000 \\
GINI & -12.30041 & 4.699491 & -2.617391 & 0.0106 \\
VOL*GINI & -123.4900 & 62.83648 & -1.965259 & 0.0529 \\
VOL & 39.37289 & 32.49037 & 1.211833 & 0.2292 \\
GC & 0.190431 & 0.165872 & 1.148058 & 0.2544 \\
J-statistic & 10.92213 & Instrument rank & 12 \\
Prob(J-statistic) & 0.142052 & & & \\
\hline
\end{tabular}

Table 2: The Effect of Education Inequality using PMG-ARDL

\begin{tabular}{|c|c|c|c|c|}
\hline Variable & Coefficient & Std. Error & t-Statistic & Prob.* \\
\hline \multicolumn{5}{|c|}{ Long Run Equation } \\
\hline$\overline{\mathrm{GINI}}$ & -1.894140 & 0.610824 & -3.100958 & 0.0024 \\
\hline GC & -0.127142 & 0.011373 & -11.17891 & 0.0000 \\
\hline VOL & 106.4538 & 29.34469 & 3.627702 & 0.0004 \\
\hline GINI*VOL & -678.9094 & 46.84135 & -14.49380 & 0.0000 \\
\hline \multicolumn{5}{|c|}{ Short Run Equation } \\
\hline COINTEQ01 & -1.638388 & 0.490519 & -3.340112 & 0.0011 \\
\hline $\mathrm{D}(\mathrm{GDP}(-1))$ & 0.572013 & 0.436950 & 1.309103 & 0.1931 \\
\hline$D(G D P(-2))$ & 0.347739 & 0.346382 & 1.003918 & 0.3175 \\
\hline $\mathrm{D}(\mathrm{GDP}(-3))$ & 0.415339 & 0.167183 & 2.484332 & 0.0144 \\
\hline $\mathrm{D}(\mathrm{GDP}(-4))$ & 0.440718 & 0.247635 & 1.779708 & 0.0777 \\
\hline$D(G D P(-5))$ & 0.110334 & 0.123414 & 0.894015 & 0.3732 \\
\hline $\mathrm{D}(\mathrm{GINI})$ & -124236.4 & 123912.4 & -1.002615 & 0.3181 \\
\hline $\mathrm{D}(\mathrm{GINI}(-1))$ & -177058.3 & 177140.1 & -0.999539 & 0.3196 \\
\hline $\mathrm{D}(\mathrm{GINI}(-2))$ & -176762.8 & 176117.6 & -1.003664 & 0.3176 \\
\hline $\mathrm{D}(\mathrm{GINI}(-3))$ & -242110.6 & 243200.7 & -0.995518 & 0.3216 \\
\hline $\mathrm{D}(\mathrm{GINI}(-4))$ & -168912.1 & 168446.8 & -1.002763 & 0.3181 \\
\hline $\mathrm{D}(\mathrm{GINI}(-5))$ & -78070.62 & 78294.21 & -0.997144 & 0.3208 \\
\hline$D(G C)$ & 0.245612 & 0.185759 & 1.322205 & 0.1887 \\
\hline $\mathrm{D}(\mathrm{GC}(-1))$ & 0.259752 & 0.202401 & 1.283354 & 0.2019 \\
\hline $\mathrm{D}(\mathrm{GC}(-2))$ & 0.153300 & 0.269134 & 0.569605 & 0.5700 \\
\hline $\mathrm{D}(\mathrm{GC}(-3))$ & 0.165401 & 0.223155 & 0.741193 & 0.4601 \\
\hline $\mathrm{D}(\mathrm{GC}(-4))$ & -0.376596 & 0.186745 & -2.016634 & 0.0460 \\
\hline $\mathrm{D}(\mathrm{GC}(-5))$ & -0.116654 & 0.207411 & -0.562432 & 0.5749 \\
\hline $\mathrm{D}(\mathrm{VOL})$ & 126401.0 & 123706.0 & 1.021785 & 0.3090 \\
\hline $\mathrm{D}(\mathrm{VOL}(-1))$ & 178107.4 & 177024.7 & 1.006116 & 0.3165 \\
\hline $\mathrm{D}(\mathrm{VOL}(-2))$ & 176428.4 & 176125.3 & 1.001721 & 0.3186 \\
\hline $\mathrm{D}(\mathrm{VOL}(-3))$ & 243593.6 & 243005.5 & 1.002420 & 0.3182 \\
\hline $\mathrm{D}(\mathrm{VOL}(-4))$ & 169136.5 & 168387.8 & 1.004447 & 0.3173 \\
\hline $\mathrm{D}(\mathrm{VOL}(-5))$ & 79576.44 & 78147.36 & 1.018287 & 0.3107 \\
\hline $\mathrm{D}\left(\mathrm{GINI} I^{*} \mathrm{VOL}\right)$ & -10414.56 & 10533.30 & -0.988727 & 0.3249 \\
\hline $\mathrm{D}\left(\mathrm{GINI}(-1)^{*} \mathrm{VOL}(-1)\right)$ & -2423.755 & 1495.171 & -1.621055 & 0.1077 \\
\hline $\mathrm{D}\left(\mathrm{GINI}(-2)^{*} \mathrm{VOL}(-2)\right)$ & 1416.237 & 2880.942 & 0.491588 & 0.6239 \\
\hline $\mathrm{D}\left(\mathrm{GINI}(-3)^{*} \mathrm{VOL}(-3)\right)$ & -810.0754 & 2019.468 & -0.401133 & 0.6891 \\
\hline $\mathrm{D}\left(\mathrm{GINI}(-4)^{\star} \mathrm{VOL}(-4)\right)$ & -1947.334 & 2375.804 & -0.819653 & 0.4141 \\
\hline $\mathrm{D}\left(\mathrm{GINI}(-5)^{*} \mathrm{VOL}(-5)\right)$ & -4344.538 & 3596.105 & -1.208123 & 0.2295 \\
\hline C & 11.60293 & 6.650636 & 1.744634 & 0.0837 \\
\hline Mean dependent var & -0.055074 & \multicolumn{2}{|c|}{ S.D. dependent var } & 6.661015 \\
\hline
\end{tabular}


Table 2. Cont.

\begin{tabular}{lccc}
\hline S.E. of regression & 2.863711 & Akaike info criterion & 3.439587 \\
Sum squared resid & 951.2973 & Schwarz criterion & 6.648181 \\
Log likelihood & -470.1384 & Hannan-Quinn criter. & 4.699499 \\
\hline
\end{tabular}

impact. This means that if business cycles drive economic agents to accumulate human capital in response to an uncertain economic environment, and drive governments also to implement expansionary economic policies, which increases economic growth, education inequality will reduce this volatility's positive impact.

All these effects are significant in the long run, those findings show the importance of considering not only the level of education but also its dispersion when understanding the link between long term growth and short term fluctuations. Therefore, when policymakers decide to increase investment in education even during economic crisis, they should take into account also how this investment is distributed or how to reduce educational inequalities.

The effect of education inequality on the growth volatility link requires more analysis using different measures of education inequality. Future research is needed in order to differentiate between the effects of negative and positive shocks, as well as domestic and external volatility.

\section{REFERENCES}

Arbache J, Sarquis SJB (2017). "Growth Volatility and Economic Growth in Brazil," Available at SSRN: https://ssrn.com/abstract=2925405

Arellano M, Stephen B (1991). "Some Tests of Specification for Panel Data: Monte Carlo Evidence and an Application to Employment Equations," Rev. Econ. Studies. 58(2): 277-297.

Baum CF, Mark ES, Steven S (2003). "Instrumental Variables and GMM: Estimation and Testing," Working Paper No. 545, Department of Economics, Boston College.

Bond SR (2002). "Dynamic Panel Data Models: A Guide to Micro Data Models Methods and Practice," Department of Economics, The Institute for Fiscal Studies, Cemmap Working Paper No. CWP09/02.

Canton E (1996). "Business Cycles in a Two-Sector Model of Endogenous Growth," Tilburg University. Available at: https://pure.uvt.nl/ws/files/526126/116.pdf

Castello A, Rafael D (2002). "Human Capital Inequality and Economic Growth: Some New Evidence," Econ. J. 112(March): C187-C200.

Gungor ND (2006). "Education, Human Capital Inequality and Economic Growth: Evidence from Turkey," Presented at ERF 13th Annual Conference on Oil: Its Impact on The Global Economy, 16-18 December, Koweit.

Habibi N (2009). "The Impact of the Global Economic Crisis on Arab Countries: A Year-End Assessment", Middle East Brief No. 40, Crown Center for Middle East Studies, Brandeis University.

Hakimian H (1998). " From East to West Asia: Lessons of Globalization, Crisis and Economic Reform" , Paper written for the World Bank/SOAS Symposium on The Changing Role of the State in the Middle East and North Africa, London, 6 May 1998.
Hassan R, Shahzad MM (2005). "Education Inequality and Economic Growth: Framework for The Evaluation of Pakistan's Education Policy", MPRA Paper No. 26351.

Hnatkovska V, Norman L (2003). "Volatility and Growth," Working Paper No. WPS3184, The World Bank.

Ibourk A, Jabrane A (2013). "Inequality in Education and Economic Growth: Empirical Investigation and Foundations: Evidence from MENA Region," Intl. J. Econ. Financ. 5(2): 111-124.

Judson RA, Ann LO (1999). "Estimating Dynamic Panel Data Models: A Practical Guide for Macroeconomists", Econ. Lett. 65(1): 9-15.

Kedir AM, Nor YMB (2012). "Panel Data Evidence on The Role of Education in The Growth-Volatility Relationship," Working Paper No. 12/04, Department of Economics, University of Leicester, UK.

Kose MA, Eswar SP, Marco ET (2005). "Growth and Volatility in an Era of Globalization," IMF Staff Papers Vol. 52, The International Monetary Fund.

Martin P, Carol AR (2000). "Long-Term Growth and Short-Term Economic Instability," Eur. Econ. Rev. 44: 359-381.

Ramey G, Valerie AR (1994). "Cross-Country Evidence on The Link Between Volatility and Growth," Working Paper No. 4959, National Bureau of Economic Research.

Ren CC, Zulkefly AK, Azlan SZ (2012). "Institutions and Foreign Direct Investment (FDI) in Mena Countries: A Panel ARDL Study". PROSIDING PERKEM VII, JILID, No. 2.

Samargandi N, Jan F, Sugata G (2015). "Is the Relationship Between Financial Development and Economic Growth Monotonic? Evidence from a Sample of Middle-Income Countries". World Development, Volume 68.

Thomas V, Yan W, Xibo F (2001). "Measuring Education Inequality: Gini Coefficients of Education," Policy Research Working Paper No. 2525, The World Bank.

Trypsteen S (2017). "The Growth-Volatility Nexus: New Evidence from an Augmented GARCH-M Model," Econ. Modelling. 63: 15-25.

Wooldridge JM (2001). "Applications of Generalized Method of Moments Estimation," J. Econ. Perspect. 15(4): 87-100. 